\title{
Understanding the impact of Bacillus thuringiensis proteins on non-target organisms
}

\author{
Tanvi Singh $^{1 *}$, Yamini Tiwari ${ }^{2}$, Garima Awasthi $^{3}$ \\ ${ }^{1,2,3}$ Vivekananda Global University, Jaipur- 303012, Rajasthan, India \\ "Corresponding author: tanvi.s@vgu.ac.in,Tel.: +91-141-4077999
}

Available online at: www.isroset.org

Received: 09/Apr/2019, Accepted: 13/Apr/ 2019, Online: 30/Apr/2019

\begin{abstract}
$\overline{\text { Abstract-Bacillus thuringiensis (Bt) is a spore-forming, gram-positive, aerobic, rod-shaped bacterium. During sporulation, } B t}$ produces proteinaceous crystals called Cry proteins that are lethal to many insects' species, so are commonly used as biological pesticide. Transgenic $B t$ crops are genetically altered to express insecticidal toxins that cause fatality of a number of general agricultural pests. The insecticidal toxins formed by $B t$ crops possess narrow range of toxicity and therefore less non-target impacts as compared to conventional insecticides. A decrease in the amount and regularity of insecticide applications are financially advantageous. In numerous regions of the world, insecticide inputs have been significantly reduced because of $B t$. The use of $B t$ crop technology might help in worldwide food security by escalating the amount and steadiness of crop yields. Though impact of $B t$ toxin on non-targeted organism is a serious issue yet no conclusion could still be drawn from several studies. This review summarizes the benefits of $B t$ crops including the impact on non-targeted organisms and $B t$ toxins having potential risks with respect to the environment.
\end{abstract}

Keywords-Bacillus thuringiensis, Bt toxin, Cry proteins, environment, non-target organisms

\section{INTRODUCTION}

Bacillus thuringiensis (Bt) is a gram-positive, aerobic, sporeforming, rod-shaped bacterium. An important trait of $B t$ is the production of proteinaceous crystals at the time of sporulation. These crystal proteins commonly called Cry proteins possess toxicity to many insects' species and thus are commonly used as biological pesticide. Bt belongs to Bacillus cereus group. However, it is differentiated from $B$. cerus by the presence of a plasmid that produces the crystal protein [1]. 2014). During sporulation, Cry protein encoding genes become active as they are controlled by RNA polymerase that gets synthesized with the formation of spores [1, 2, 3].

$B t$ was originally isolated in 1901 by a Japanese biologist Shigetane Ishiwatari. He investigated that the sotto disease (sudden-collapse disease), which killedhuge populations of silkworms(Bombyx mori), was caused by Bacillus thuringiensis. Initially, Ishiwatari named the bacterium Bacillus sotto. Later in 1911, Ernst Berliner isolated bacteria that killed a Mediterranean flour moth (Ephestia kuehniella) and rediscovered Bt. He renamed it Bacillus thuringiensis after Thuringia, the German town where the moth was found [4]. Bt is a soil dwelling, ubiquitous bacteria, and has been found in all kind of topography, including desert, beaches, and tundra habitats. Itis largely used in agriculture, especially organic farming [5].This article reviews impact of $B t$ toxins and $B t$ derived transgenic crops on the environment including non target organisms, their benefits and drawbacks. Rest of the paper is organized as follows, Section II describes the structure of $B t$ protein, Section III describes the mode of action of Bt endotoxins, Section IV contain the information about applications of $B t$ technology, section $\mathrm{V}$ explain thebenefits of $B t$ technology, Section VI describes potential risks of $B t$ crops, Section VII contain the impact of $B t$ toxins on non targeted organisms, and Section VIII concludes review with future directions.

\section{Structure of $B t$ protein}

Cry toxins and Cyt-toxins are two types of insecticidal proteins found during sporulation when crystalline bodies are produced. Cry toxins are so called as they are present in form of crystals. Mnemonic Cry was derived from parasporal crystal proteins of Bacillusthuringiensis which demonstrated noticeable toxic effects on target organismsor on other proteins which show homology to Cry protein. Cyt-toxins are named due to in vitro cytolytic activity possessed by them. Mnemonic Cyt referred to parasporal crystal proteins of Bacillus thuringiensis showing hemolytic activity, as well as to other protein having homology to Cyt protein. This kind of 
naming system has been accepted for the vegetatively produced $B t$-toxins. These proteins have been précised the mnemonic Vip [6, 7].

X-ray crystallographic methods revealed the 3-dimensional crystal structure of the Cry-proteins viz.coleopteran specific Cry3Aa, Cry3Bb and Cry8Ea1 [8, 9, 10], dipteran specific Cry4Aa and Cry4Ba [11, 12], lepidopteran specific Cry1Aa [13] and lepidopteran/dipteran specific Cry2Aa [14]. Moreover, 3-dimensional structure of Cyt-proteins comprisedof stimulated Cyt2Ba and untreated Cyt2Aa [15, 16].

The general 3-D crystal structure of most of the Cry toxins and Cyt-toxins has been illustrated to be similar, each containing three domains [1, 17]. Domain I is made up of seven $\alpha$-helices where the central helix $-\alpha 5$ is hydrophobic and is surrounded by six amphipathic helices. The helical domain I share structural resemblance with other pore forming bacterial toxins like diphtheria toxin, colicin A and cytolycin A [18]. Outer helices of domain I are amphipathic in nature and are longer than $30 \AA$ in length [19]. In domain II three antiparallel $\beta$-sheets piled up to form a $\beta$-prism with pseudo three-fold symmetry [8]. Out of three, two are made up of four strands in the form of a Greek key motif and are exposed to solvent [12]. The third sheet is stacked next to domain I and is also assembled in a Greek-key-like pattern with a petite alpha-helix and three strands [19]. Domain III has been revealed to comprise of two antiparallel $\beta$-sheets that look like a $\beta$-sandwich structure having jelly roll topology [12]. Both the sheets are made up of five strands, with the inner sheet packing against domain II and outer sheet towards the solvent. Two long loops stretch from one end of the domain and get in contact with domain I [13].

\section{Mode of action of $\mathrm{Bt}$ endotoxins}

$B t$ toxins get activated in the gut, therefore, for insect mortality to occur, they should be eaten by the insect. $B t$ endotoxin crystals dissolve in the alkaline ambiance of midgut of host insect [20].

The proteins are present as protoxins which get activated in the presence of specific protease. As a result of proteolysis, toxins bind to receptors present in the brush border membrane of midgut which open the pores that cause disruption in the solute movement through the gut epithelium and torrent of water, resulting in death of the host host [21]. Alkaline conditions, specific receptors and specific proteases are required for proper working of Bt.It is not detrimental to mammals as these conditions are not available as such [22]. Mode of action of $B t$ involves:

Firstly the insect consumes $B t$ crystals and spores. In alkaline medium of gut of insect, activation of $B t$ pro-toxin to activated $B t$ toxin occurs. Then $B t$ toxin bind to specific receptors present in the gut.These proteins then putrefy the wall of gut, permitting the gut bacteria and spores to penetrate the host body. The host insect dies due to starvation and proliferation of spores take place [23].

\section{Applications of $B t$ technology}

\section{Bt crops}

Genetic engineering of certain crops has been done to integrate genes which are derived from other species and offer agronomic and nutritional advantages, like resistance to viruses, insect pests, or to ecologicalsettings like low water availability. Transgenic $B t$ crops are genetically altered to express insecticidal proteins that cause fatality toa number ofgeneral agricultural pests. The genes from Bacillus thuringiensiscoding for such proteinsare introduced into the genome of the preferred crop plant. Crop plants that have been genetically altered to express $B t$ toxins include cotton, sweet corn, potato, eggplant, oilseed, rice, rape (canola), broccoli, tomato, chickpea, collards, spinach, tobacco, cauliflower and soybean [24].

\section{Chitinase production}

Chitinases are the chitin degrading enzymes that can be found in the exoskeletons of arthropods, cell walls of fungi, and the shells of nematodes and crustaceans [25]. Chitinases possess numerous uses in the sphere of medicinal services due to their immunomodulating and antibacterial impacts, as well as in horticulture for management of plant pathogens and creation of antifungal substances [26]. Chitinase enzymes were found to be present in Bt. After several decades of field use; studies have reported the biological activity of bacterial chitinase [27, 28, 29]. Chitinases act synergistically with Cry and therefore provide improved rates of mortality. These enzymes break the invertebrates' chitinous exoskeleton and allow bacteria to invade the tissues, thus leading to septicemia followed by death. Researchers have tried to accelerate the production of $B t$ biopesticides, as chitinases increase the $B t$ toxicity in biological tests. To ensure the increased production of $B t$ biopresticide, chitin was supplemented to the culture media to stimulate the secretion of chitinase by bacteria [24].

\section{Benefits of $B t$ Technology}

\section{Decreased Risk as Compared to Conventional Insecticides \\ The insecticidal toxins produced by $B t$ crops have narrow range of toxicity and therefore less non-target impacts as compared to conventional insecticides. For example, numerous natural enemies reactedharmfully to foliar applications of wide-range pyrethroids in contrast to selective insecticides like $B t$ toxins, indoxacarb, and spinosad that were used to fight lepidopteran pests in sweet corn}


agroecosystems [30]. Lesser herbivore and predator abundance was found in non-transgenic control plots treated with insecticides as compared to unsprayed $B t$ fields. This effect was chiefly observed for predator populations in nontransgenic plots treated with pyrethroids like cyfluthrin, bifenthrin and lambda-cyhalothrin [31]. Likewise, more abundance of spiders was observed in $B t$ cotton, corn, and potato as compared to crops managed by conventional insecticides including systemic neonicotinoid seed treatments, foliar pyrethroid sprays, and organophosphate soil applications at planting [32].

\section{Financial Savings}

A decrease in the amount and regularity of insecticide applications are financially advantageous. In numerous regions of the world, insecticide inputs have been significantly reduced because of $B t$ cotton. It is apparent that $B t$-based production systems are more sustainable with reference to pest management and also encompass the ability to improve agricultural diversity through reduced chemical inputs [33].

\section{Worldwide Food Security}

With the increasing human population there is need for augmented global food production and security. The use of $B t$ crop technology might help in this goal by escalating the amount and steadiness of crop yields, for example, corn yields were protected or increased by the management of European corn borer. In addition, stored $B t$ corn is protected against lepidopteran pests and mycotoxin which if introduced in food supply, pose a threat to the humans and livestock health [33].

\section{Potential Risks of $B t$ Crops}

\section{Presence in Human Food Supply}

In digestive tract of vertebrates, $B t$ toxins hastily break down due to presence of acidic environment [34]. Transgenic corn (Bt corn) containing Cry9C proteins, commercially available under name StarLink ${ }^{\text {TM }}$ were planted in the United States.Due to their importunate presence in vertebrate gut these were approved only for ethanol production and animal feed. StarLink and Taco Bell ${ }^{\circledR}$ taco shells which were meant for human consumption were confiscated from the market when Cry9C protein traces were found in cornmeal [35]. In spite of this, none of the allergenic reactions were reported due to presence of Cry9C in food products. Irrespective of lack of evidences about the risk associated with $B t$ food products, consumption by humans and commercial acceptance for some products like $B t$ potatoes has been persuaded in various countries [36].Thus, in spite of restricted outcomes on the human population, precautions need to be maintained to exclude the existence of unapproved genetically modified products inflowing the human food chain.

\section{Pleiotropic Effects of Genetic Transformation}

Incorporation of a $B t$ gene into a crop plant results in astounding and inadvertent pleiotropic consequence that alters the plant from its non-transgenic form [37]. Increased lignin content in transgenic plants was reported as pleiotropic effect in $B t$ corn. This trait resulted in decreased decomposition rates in the soil [38]. Nonetheless, further reports have challenged this inference and exhibited no dissimilarities in decomposition rate [39]. In corn, a superfluous pleiotropic consequence of Cry1F transformation in corn has been reported in corn leafhoppers Dalbulusmaidis (Hemiptera: Cicadellidae), which is a non $B t$ target organism, probably due to altered plant traits, like foliar pubescence, leaf vein characteristics and plant chemistry [40].

\section{Impact of Bt Toxins on Non Targeted Organisms}

Extensive studies have been conducted past 20 years on the harmful effects of $B t$ toxins on non- targeted organisms and various aspects of environment. Contrasting evidence of effects on non-targets, ranging from unobservable effects of intake of $B t$ transgenic crops [41, 42, 43, 44], to number of harmful effects (viz. delay in development, reduction in weight gain, changes in behavior or increased mortality) on beneficial organisms like pollinators [45], non-target arthropods [46,47,48], parasitoids [49] and predators [50, 51] are present.

\section{Pollinators and butterflies}

In terrestrial ecosystem, pollinators occupy an important place. Honey bees being the most profuse and prevailing pollinators globally, were used as indicators for the Pest Management Regulatory Agency of Bt crops [52]. Feeding trials with plant pollen containing $B t$ toxins have been carried out on honey bees extensively with no lethal effect on their prolonged existence, nourishment, behavior, dismutase activity, growth of hypopharyngeal glands and bacterial communities present in their intestines [53, 54, 55, 56]. In contrast to these studies Han et al. [57] reported that honey bees reared on pollens of cotton plants expressing Cry1Ac and CpTI toxins exhibited a disturbing feeding behavior. Duan et al. [58] reported no adverse effect on the survival and development of Oriusinsidiosus (Heteroptera: Anthocoridae) nymphs, when the nymphs were continuously fed on bee pollen diet with a hazard exposure dose of the Cry3Bb1 protein for about 14 days. Niu et al. [59] conducted a study on A. suturalis and H. luteolus to estimate the toxicity of $B t$ cotton varieties expressing Cry1Ac, Cry2Ab, Cry1Ac toxins. No considerable inflation was observed in the mortality of either species after nurturing them on $B t$ cotton plants for about 7 days. General studies exhibited negligible or no lethal effect of $B t$ toxins on pollinators, nevertheless the risks associated may be depend on the type of insect and experimental system [60, 61]. 


\section{Microorganisms and macroorganisms}

The possible impact of $B t$ crops on micro and macroorganisms depend on the biological activity and persistence of $B t$ proteins. $B t$ toxins have the characteristic to bind to clay particles and humus in soils, and become defiant to biodegradation, but retain larvicidal activity [62].

Table 1: Important studies on effect of $B t$ proteins on non target organisms (2015-2019).

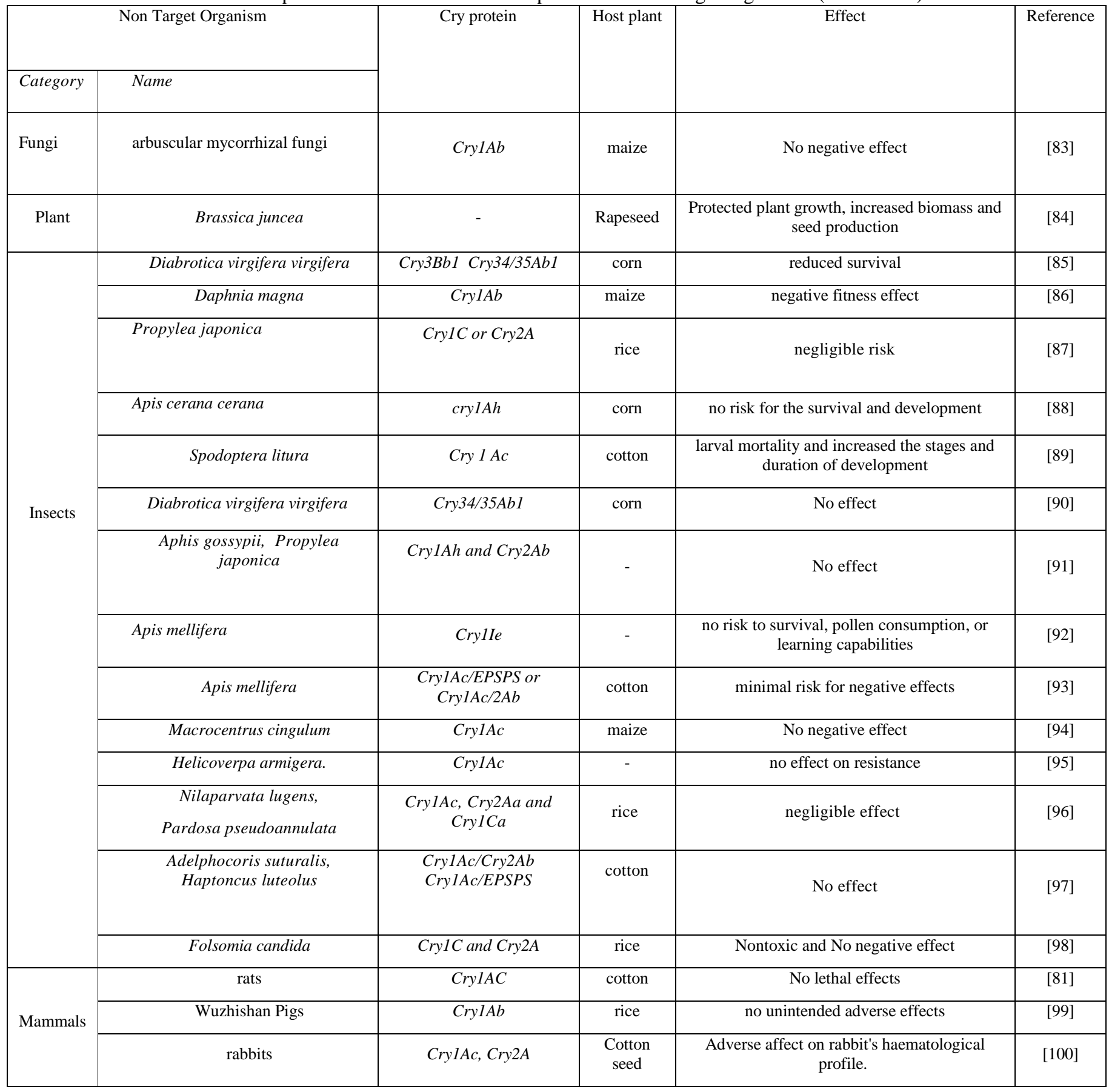

Generally, no deadly effects of $\mathrm{Bt}$ proteins on macroorganisms like collembola and mites have been reported [63, 64, 65]. In a study, Bt maize straw brought about alteration in bacterial community of
Eisenia fetida casts [66]. A number of studies on the effects of Btcrops on soil microorganisms have failed to find any significant effects in laboratory experiments, in microcosm, and under field conditions. To date, the direct effects 
of $B t$ protein on soil microorganisms is unclear [67, 68, 69, 70, 71, 72].

\section{Aquatic organisms}

Even though water organisms are not directly exposed to $B t$ proteins present in crop plants but indirectly $B t$ toxins can effect aquatic organisms, exposed due to run-off transfer of $B t$ residues bound to soil and crop material. Quite a few studies were done to assess the effects of $B t$ vegetation on water organisms [73, 74, 75, 76]. Order Trichoptera have aquatic larvae. Numerous Cry toxins like Cry1Ab, Cry1Ac, Cry1A.105, Cry1F, Cry2Ab2, and Vip3A aim the Lepidopterans and consequently, can also target the phylogenetically near Trichoptera. Also a few studies on crustaceans pointed out the possible risks of $B t$ toxins to Daphnids [77]. Different effects on Daphnia fed with Cry1Ab-containing maize were, decreased fecundity, decreased total number of eggs, less individuals attaining maturity and less number of juveniles per stage [73, 77]. However, Holderbaum et al. [73] showed no effect of Cry1Ab maize on cumulative fecundity and age at maturation. In Hyallelaaszteca no effect on mortality and growth was observed when fed with CrylAb-containing maize but showed increased mortality when fed with Cry1Ac-containing cotton [74, 78]. Since literature provides mixed response of $B t$ in aquatic organisms, therefore additional research is needed for the evaluation of effects of $B t$ crops on aquatic organisms.

\section{Birds and mammals}

Experiments were carried out to study the effect of $B t$ transgenic crops fed to livestock, poultry and other animals. The parameters studied were hematology, immune response, growth rate, weight gain, food intake, feed efficiency. No effect of $B t$ maize was observed on calves and pigs in some studies. However, certain other studies report higher level of severe inflammation in stomach, higher uterus weight in pigs, lower proportion of $\mathrm{T}$ helper and $\mathrm{T}$ cytotoxic cells within lymphocytes and higher spleen weight in broilers when fed with $B t$ maize [79]. Sajjad et al. [80] studied the effect of $B t$ cotton on mice and concluded no harmful effect on model animal. Also, no fatal consequence of transgenic $B t$ crystals on the continued existence of rats and earthworm was observed [81]. Thus, several researchers have reported the toxic effects of $B t$ proteins on animals while others showed no harmful effects [82]. It is the task of researchers to evaluate of effects of $B t$ crops on animals with further studies.

\section{Conclusions}

The chance of occurrence of $B t$ toxins in the environment and its effect on non target organisms is complicated and inconsistent. It totally depends upon crop type, transgenic incidents, geographic conditions, and other factors. The impact of $B t$ toxins on the environment is extensively debatable. Various approaches have been proposed for future research regarding environmental management of $B t$ crops and their incorporation into integrated pest management and resistance management systems. Regardless of the concerns linked with $B t$ crops, substantial reductions in chemical usage is observed and this approach is environmental friendly as compared to other pest restraint approaches, especially those methods in which broad-spectrum insecticides are used.

\section{REFERENCES}

[1] L. Palma, D. Muñoz, C. Berry, J. Murillo, P. Caballero, "Bacillus thuringiensis toxins: an overview of their biocidal activity", Toxins, Vol. 6, Issue.12, pp. 3296-3325, 2014.

[2] S.A. López-Pazos, J. Cerón, "Biological Activity of Insecticidal Toxins: Structural Basis, Site-Directed Mutagenesis and Perspectives. In: Figurski D. (eds) Genetic Manipulation of DNA and Protein-Examples from Current Research", InTech, 2013. DOI: $10.5772 / 55895$

[3] C. Deng, Q. Peng, F. Song, D. Lereclus, "Regulation of cry gene expression in Bacillus thuringiensis", Toxins, Vol. 6, Issue. 7, pp. 2194-2209, 2014.

[4] R. Arora, "Microbial control in insect pest management: achievements and challenges, Biological and molecular approaches in pest management", Scientific Publishers, Jodhpur, pp. 97-152, 2015.

[5] K.S. Rao, D. Pattanayak and R. Sreevathsa, "Bt Insecticidal Crystal Proteins: Role in Insect Management and Crop Improvement", In Biocontrol of Lepidopteran Pests, pp. 53-70. Springer, Cham, 2015.

[6] N. Crickmore, D.R. Zeigler, J. Feitelson, E. Schnepf, J. Van Rie, D. Lereclus, J. Baum and D.H. Dean, "Revision of the nomenclature for the Bacillus thuringiensis pesticidal crystal proteins", Microbiol Mol Biol Rev, Vol. 62, Issue. 3, pp. 807-813, 1998.

[7] M. Soberón, J.A. López-Díaz, A. Bravo, "Cyt toxins produced by Bacillus thuringiensis: a protein fold conserved in several pathogenic microorganisms", Peptide,. Vol. 41, pp. 87-93, 2013.

[8] J.D. Li, J. Carroll, D.J. Ellar, "Crystal structure of insecticidal $\delta$ endotoxin from Bacillus thuringiensis at 2.5 A resolution", Nature, Vol. 353, pp. 815-821, 1991.

[9] N. Galitsky, V. Cody, A. Wojtczak, D. Ghosh, J.R. Luft, W. Pangborn, L. English, "Structure of the insecticidal bacterial $\delta$ endotoxin Cry3Bb1 of Bacillus thuringiensis", Acta Crystallogr D Biol Crystallogr, Vol. 57, Issue. 8, pp. 1101-1109, 2001.

[10] S. Guo, S. Ye, Y. Liu, L. Wei, J. Xue, H. Wu, F. Song, J. Zhang, $\mathrm{X}$. Wu, D. Huang, Z. Rao, "Crystal structure of Bacillus thuringiensis Cry8Eal: An insecticidal toxin toxic to underground pests, the larvae of Holotrichia parallela”, J Struct Biol, Vol. 168, Issue. 2, pp. 259-266, 2009.

[11] P. Boonserm, P. Davis, D.J. Ellar, J. Li, "Crystal structure of the mosquito-larvicidal toxin Cry4Ba and its biological implications", J Mol Biol, Vol. 348, Issue. 2, pp. 363-382, 2005.

[12] P. Boonserm, M. Mo, C. Angsuthanasombat, J. Lescar, "Structure of the functional form of the mosquito larvicidal Cry4Aa toxin from Bacillus thuringiensis at a 2.8-angstrom resolution",J Bacteriol, Vol. 188, Issue. 9, pp. 3391-3401, 2006.

[13] P. Grochulski, L. Masson, S. Borisova, M. Pusztai-Carey, J.L. Schwartz, R. Brousseau, M. Cygler, "Bacillus thuringiensis CrylA (a) Insecticidal Toxin: Crystal Structure and Channel Formation", J Mol Biol, Vol. 254, Issue. 3, pp. 447-464, 1995. 
[14] R.J. Morse, T. Yamamoto, R.M. Stroud, "Structure of Cry2Aa suggests an unexpected receptor binding epitope", Structure, Vol. 9, Issue. 5, pp. 409-417, 2001.

[15] J. Li, P.A. Koni, D.J. Ellar, "Structure of the mosquitocidal dendotoxin CytB from Bacillus thuringiensis sp. kyushuensis and implications for membrane pore formation", J Mol Biol, Vol. 257, Issue. 1, pp. 129-152, 1996.

[16] S. Cohen, O. Dym, S. Albeck, E. Ben-Dov, R. Cahan, M. Firer, A. Zaritsky, "High-resolution crystal structure of activated Cyt $2 \mathrm{Ba}$ monomer from Bacillus thuringiensis subsp. Israelensis", J Mol Biol, Vol. 380, Issue. 5, pp. 820-827, 2008.

[17] A. Bravo, S.S. Gill, M. Soberon, "Mode of action of Bacillus thuringiensis Cry and Cyt toxins and their potential for insect control", Toxicon, Vol. 49, Issue. 4, pp. 423-435, 2007.

[18] Z. George, N. Crickmore, "Bacillus thuringiensis applications in agriculture, In Bacillus thuringiensis biotechnology", pp. 19-39. Springer, Dordrecht, 2012.

[19] C.R. Pigott, D.J. Ellar, "Role of receptors in Bacillus thuringiensis crystal toxin activity", Microbiol Mol Biol Rev, Vol. 71, Issue. 2, pp. 255-281, 2007.

[20] R.A. Ibrahim, D.M. Shawer, "Transgenic Bt-plants and the future of crop protection (an overview)", International Journal of Agricultural and Food Research, Vol. 3, Issue. 1, pp. 14-40, 2014.

[21] G. Sanahuja, R. Banakar, R.M. Twyman, T. Capell, P. Christou, "Review article Bacillus thuringiensis: a century of research, development and commercial applications", Plant Biotechnol J, Vol. 9, Issue. 3, pp. 283-300, 2011.

[22]. M.S. Koch, J.M. Ward, S. L. Levine, J.A. Baum, J.L. Vicini, B.G. Hammond, "The food and environmental safety of Bt crops", Front Plant Sci, Vol. 6, Issue. 283, 2015.

[23]. R. Schünemann, N. Knaak, L.M. Fiuza, "Mode of action and specificity of Bacillus thuringiensis toxins in the control of caterpillars and stink bugs in soybean culture", ISRN microbiology, Vol. 201, pp. 1-12, 2014.

[24]. A.L. Melo, V.T. Soccol, C.R. Soccol, "Bacillus thuringiensis: mechanism of action, resistance, and new applications: a review", Critica Rev Biotechnol, Vol. 36, Issue. 2, pp. 317-326, 2016.

[25]. A.S. Rathore, R.D. Gupta, "Chitinases from bacteria to human: properties, applications, and future perspectives", Enzyme research, Vol. 2015, pp. 1-8, 2015.

[26]. D. Bhattacharya, A. Nagpure, R.K. Gupta, "Bacterial chitinases: properties and potential”, Critica Rev Biotechnol, Vol. 27, Issue.1, pp. 21-28, 2007.

[27]. F. Saleem, U. Nisar, A. Younas, F. Jabeen, J.I. Qazi, N. Khursheed, N. Munir, S. Naz and A.R. Shakoori, "Molecular characterisation of Bacillus chitinase for bioconversion of chitin waste", Nat Prod Res, Vol. 30, Issue. 6, pp. 720-723, 2016.

[28]. E. A Veliz, P. Martínez-Hidalgo, A. M Hirsch, "Chitinaseproducing bacteria and their role in biocontrol", AIMS Microbiology, Vol. 3, Issue. 3, pp. 689-705, 2017.

[29]. A. Oyeleye, Y.M. Normi, "Chitinase: diversity, limitations, and trends in engineering for suitable applications", Biosci Rep, Vol. 38, Issue. 4, 2018

[30]. C. Then, A. Bauer-Panskus, "Possible health impacts of Bt toxins and residues from spraying with complementary herbicides in genetically engineered soybeans and risk assessment as performed by the European Food Safety Authority EFSA", Environmental Sciences Europe, Vol. 29, Issue. 1, 2017.

[31]. L.L. Wolfenbarger, S.E. Naranjo, J.G. Lundgren, R.J. Bitzer, L.S. Watrud, "Bt crop effects on functional guilds of non-target arthropods: A meta-analysis", PLoS One, Vol. 3, Issue. 5, e2118, 2008.
[32]. J. A. Peterson, J.G. Lundgren, J.D. Harwood, "Interactions of transgenic Bacillus thuringiensis insecticidal crops with spiders (Araneae)" J Arachnol, Vol. 39, Issue. 1, pp. 1-21, 2011

[33]. J. A. Peterson, J. J. Obrycki, J. D. Harwood, "Bacillus thuringiensis: Transgenic Crops", Encyclopedia of Environmental Management CRC Press, pp. 307-320, 2013.

[34]. M. Mendehlson, J. Kough, Z. Vaituzis, K. Matthews, "Are Bt crops safe?”, Nat Biotechnol, Vol. 21, Issue. 9, pp. 1003-1009, 2003.

[35]. S. Holm, “When They Don't Want Your Corn: The Most Effective Tort Claims for Plaintiffs Harmed by Seed Companies Whose Genetically Engineered Seeds Produced More Problems Than Profits", Hamline L Rev, Vol. 38, pp. 557, 2015.

[36]. T. Ishii, M. Araki, "Consumer acceptance of food crops developed by genome editing”, Plant cell rep, Vol. 35, Issue. 7, pp. 1507-1518, 2016.

[37]. M. Robischon, "Potential Environmental Impact of InsectResistant Transgenic Trees", In: Biosafety of Forest Transgenic Trees. Springer, Dordrecht, pp. 173-194, 2016.

[38]. A.G. Enikeev, T.V. Kopytina, L.A. Maximova, J.V. Nurminskaya, S.G. Shvetsov, "Implications of plants genetic transformation assessed by geneticist, biochemist and physiologist", J stress physiol biochem, Vol. 11, Issue. 4, 2015.

[39]. M. Faraji, L.L. Fonseca, L. Escamilla-Treviño, J. Barros-Rios, N.L. Engle, Z.K. Yang, T.J. Tschaplinski, R.A. Dixon, E.O. Voit, "A dynamic model of lignin biosynthesis in Brachypodium distachyon”, Biotechnol Biofuels, Vol. 11, Issue. 1, pp. 253, 2018.

[40]. E.G. Virla, M. Casuso, E.A. Frias, "A preliminary study on the effects of a transgenic corn event on the non-target pest Dalbulus maidis (Hemiptera: Cicadellidae)”, Crop Prot, Vol. 29, Issue. 6, pp. 635-638, 2010.

[41]. A. Hilbeck, R. Binimelis, N. Defarge, R. Steinbrecher, A. Székács, F. Wickson, M. Antoniou, P.L. Bereano, E.A. Clark, M. Hansen, E. Novotny, "No scientific consensus on GMO safety", Environ Sci Eur, Vol. 27, Issue. 1, pp. 4, 2015.

[42]. D.C. Resende, S.M. Mendes, R.C. Marucci, A.D.C. Silva, M.M. Campanha, J.M. Waquil, "Does Bt maize cultivation affect the nontarget insect community in the agro ecosystem?", Rev Bras Entomol. Vol. 60, Issue. 1, pp. 82-93, 2016.

[43]. J. Van Den Berg, J.F. Warren, H. Du Plessis, "The potential effect of Bt maize on Chrysoperla pudica (Neuroptera: Chrysopidae)", Environ entomol, Vol. 46, Issue 2, pp. 413-417, 2017.

[44]. J.C. Tian, X.P. Wang, Y. Chen, J. Romeis, S.E. Naranjo, R.L. Hellmich, P. Wang, A.M. Shelton, "Bt cotton producing CrylAc and Cry2Ab does not harm two parasitoids, Cotesia marginiventris and Copidosoma floridanum", Sci rep, Vol. 8, Issue. 1, pp. 307, 2018.

[45]. M.T. Renzi, M. Amichot, D. Pauron, S. Tchamitchian, J.L. Brunet, A. Kretzschmar, S. Maini, L.P. Belzunces, "Chronic toxicity and physiological changes induced in the honey bee by the exposure to fipronil and Bacillus thuringiensis spores alone or combined", Ecotoxicol environ saf, Vol. 127, pp. 205-213, 2016.

[46]. A. Lang, M. Otto, "Feeding behaviour on host plants may influence potential exposure to Bt maize pollen of Aglais Urticae larvae (Lepidoptera, Nymphalidae)", Insects, Vol. 6, Issue. 3, pp. 760-771, 2015.

[47]. T. Bøhn, G.L. Lövei, "Complex outcomes from insect and weed control with transgenic plants: ecological surprises?", Front Environ Sci, Vol. 5, pp.60, 2017.

[48]. P.B. Woodbury, A. DiTommaso, J. Thies, M. Ryan, J. Losey, "Effects of transgenic crops on the environment", In: Coll M, Wajnberg E. (eds) Environmental pest management: challenges for agronomists, ecologists, economists and policymakers. 1st edn. Wiley, Hoboken, pp. 131, 2017. 
[49]. D. Ndolo, J. Songa, G. Lövei, "Tri-Trophic Impacts of BtTransgenic Maize on Parasitoid Size and Fluctuating Asymmetry in Native vs. Novel Host-Parasitoid Interactions in East Africa", Insects, Vol. 9, Issue. 2, pp. 38, 2018.

[50]. G.O. Magalhães, A.M. Vacari, V.L. Laurentis, S.A. De Bortoli, R.A. Polanczyk , "Interactions of Bacillus thuringiensis bioinsecticides and the predatory stink bug Podisus nigrispinus to control Plutella xylostella”, J Appl Entomol, Vol. 139, Issue. 1-2, pp. 123-133, 2015.

[51]. Y. Wang, Y. Liu, J. Zhang, N. Crickmore, F. Song, J. Gao, C. Shu, "Cry78Aa, a novel Bacillus thuringiensis insecticidal protein with activity against Laodelphax striatellus and Nilaparvata lugens", $\mathrm{J}$ Invertebr Pathol, Vol. 158, pp. 1-5, 2018.

[52]. EPA (Environmental Protection Agency) "Biopesticides Registration Action Document-Bacillus thuringiensis Plantincorporated Protectants", U.S. Environmental Protection Agency, Washington, DC. pp. 481, 2001.

[53]. D. Babendreier, D. Joller, J. Romeis, F. Bigler, F. Widmer, "Bacterial community structures in honeybee intestines and their response to two insecticidal proteins", FEMS Microbiol. Ecol. Vol. 59, pp. 600-610, 2007.

[54]. R. Rose, G.P. Dively, "Effects of insecticide treated and lepidopteran-active Bt transgenic sweet corn on the abundance and diversity of arthropods", Environmental Entomology, Vol. 36, pp. 1254-1268, 2007.

[55]. J.L. Hofs, A.S. Schoeman, J. Pierre, "Diversity and abundance of flower-visiting insects in Bt and non-Bt cotton fields of Maputaland (KwaZulu Natal Province, South Africa)", . Int. J. Trop. Insect Sci, Vol. 28, pp. 211-219, 2008.

[56]. P. Han, C.Y. Niu, C.L. Lei, J.J. Cui, N. Desneux, "Use of an innovative T-tube maze assay and the proboscis extension response assay to assess sublethal effects of GM products and pesticides on learning capacity of the honey bee Apis mellifera L.", Ecotoxicology Vol. 19, pp. 1612-1619, 2010b.

[57]. P. Han, C.Y. Niu, C.L. Lei, J.J. Cui, N. Desneux, "Quantification of toxins in a CrylAc $+C p T I$ cotton cultivar and its potential effects on the honey bee Apis mellifera L." Ecotoxicology, Vol. 19, pp. 1452-1459, 2010a.

[58]. J. J. Duan, D. Teixeira, J. E. Huesing \& C. Jiang, “Assessing the risk to nontarget organisms from Bt corn resistant to corn rootworms (Coleoptera: Chrysomelidae): Tier-I testing with Orius insidiosus (Heteroptera: Anthocoridae)", Environmental Entomology, Vol. 37, Issue. 3, pp. 838-844, 2014.

[59]. L. Niu, Z. Tian, H. Liu, H. Zhou, W. Ma, C. Lei \& L. Chen, "Transgenic Bt cotton expressing CrylAc/Cry2Ab or CrylAc/EPSPS does not affect the plant bug Adelphocoris suturalis or the pollinating beetle Haptoncus luteolus", Environmental pollution, Vol. 234, pp. 788-793, 2018.

[60]. B.A. Schaal, "Biodiversity, Biotechnology and the Environment", Biodiversity and the Law: Intellectual Property, Biotechnology and Traditional Knowledge, 2012.

[61]. M. Arshad, H. A. A. Khan, M. A. ur Rehman \& N. A. Saeed, "Incidence of insect predators and parasitoids on transgenic Bt cotton in comparison to non-Bt cotton varieties", Pakistan Journal of Zoology, Vol. 47, Issue. 3, 2015.

[62]. A. G. Viktorov, "Influence of Bt-plants on soil biota and pleiotropic effect of $\delta$-endotoxin-encoding genes", Russian Journal of Plant Physiology, Vol. 55, Issue. 6, pp. 738-747, 2008.

[63]. L. Hönemann, W. Nentwig, "Are survival and reproduction of Enchytraeus albidus (Annelida: Enchytraeidae) at risk by feeding on Bt-maize litter?" European Journal of Soil Biology, Vol. 45 Issue. 4, pp. 351-355, 2009.

[64]. Y. Y. Bai, R H. Yan, G. Y Ye, F. Huang, D. S. Wangila, J. J. Wang, J. J. et al, "Field response of aboveground non-target arthropod community to transgenic Bt-CrylAb rice plant residues in postharvest seasons". Transgenic research, Vol. 21, Issue. 5, pp. 1023-1032, 2012.

[65]. M. Arias-Martín, M. García, M. J. Luciáñez, F. Ortego, P. Castañera, G. P. Farinós, "Effects of three-year cultivation of CrylAb-expressing Bt maize on soil microarthropod communities". Agriculture, Ecosystems \& Environment, Vol. 220, pp. 125-134, 2016.

[66]. Y. Shu, Y. Zhang, H. Zeng, Y. Zhang, J. Wang, "Effects of CrylAb Bt maize straw return on bacterial community of earthworm Eisenia fetida." Chemosphere, Vol. 173, pp. 1-13, 2017.

[67]. O. G. G. Knox, D. B. Nehl, T. Mor, G. N. Roberts, V. V. S. R. Gupta, "Genetically modified cotton has no effect on arbuscular mycorrhizal colonisation of roots. " Field Crops Research, Vol. 109 Issue.1-3, pp. 57-60, 2008.

[68]. A. P. Oliveira, M. E. Pampulha, J. P. Bennett, “A two-year field study with transgenic Bacillus thuringiensis maize: effects on soil microorganisms". Science of the Total Environment, Vol. 405, Issue.1-3, pp. 351-357, 2008.

[69]. R. Miethling-Graff, S. Dockhorn, C. C. Tebbe, "Release of the recombinant Cry3Bb1 protein of Bt maize MON88017 into field soil and detection of effects on the diversity of rhizosphere bacteria". European Journal of Soil Biology, Vol. 46, Issue. 1, pp. 41-48, 2010.

[70]. F. Tan, J. Wang, Y. Feng, G. Chi, H. Kong, H. Qiu, S. Wei, "Bt corn plants and their straw have no apparent impact on soil microbial communities" Plant and soil, Vol. 329 Issue. 1-2, pp. 349. 364. 2010.

[71]. M. Xie, Y. J. Zhang, D. L. Peng, G. Wu, P. Xu, J. J. Zhao, Z. R. Zhang, "Field studies show no significant effect of a CrylAb/Ac producing transgenic cotton on the fungal community structure in rhizosphere soil'". European journal of soil biology, Vol. 73, pp. 6976. 2016

[72]. L. Zhaolei, B. Naishun, C. Xueping, C. Jun, X. Manqiu, S. Zhiping, F. Changming, et al, "Soil incubation studies with CrylAc protein indicate no adverse effect of Bt crops on soil microbial communities." Ecotoxicol. Environ. Saf., Vol. 152, pp. 33-41, 2018.

[73]. D. F. Holderbaum, M. Cuhra, F. Wickson, A I. Orth, R. O. Nodari, T. Bøhn, "Chronic responses of Daphnia magna under dietary exposure to leaves of a transgenic (event MON810) Bt-maize hybrid and its conventional near-isoline". J. Toxicol. Environ. Health, Vol. 78, Issue, 15, pp. 993-10072015.

[74]. S. A. Whiting, M. J. Lydy, "A site-specific ecological risk assessment for corn-associated insecticides". Integrated environmental assessment and management, Vol 11, Issue 3, pp. 445-458, 2015.

[75]. T. Bøhn, C. M. Rover, P. R. Semenchuk, "Daphnia magna negatively affected by chronic exposure to purified Cry-toxins". Food Chem. Toxicol, Vol. 91, pp. 130-140, 2016

[76]. L. Zhang, R. Guo, Z. Fang, B Liu, "Genetically modified rice BtShanyou63 expressing CrylAb/c protein does not harm Daphnia magna.” Ecotoxicol. Environ. Saf., Vol. 132, pp. 196-201, 2016.

[77]. A. Pott, M. Otto, R. Schulz, "Impact of genetically modified organisms on aquatic environments: Review of available data for the risk assessment." Science of The Total Environment, Vol. 635, Issue. 687-698, 2018.

[78]. Y. L. Li, J. Du, Z. X. Fang, J. You, "Dissipation of insecticidal CrylAc protein and its toxicity to nontarget aquatic organisms." Journal of agricultural and food chemistry, Vol. 61 Issue. 46, pp. 10864-10871, 2013

[79]. C. J. de Vos, M. Swanenburg, "Health effects of feeding genetically modified (GM) crops to livestock animals: A review. " Food and Chemical Toxicology, Vol. 117, pp. 3-12, 2018.

[80]. A. M. Sajjad, A. Yasmeen, S. Ahmad, \& U. Sagheer, "Determination of the persistence frequency of different components of the crylAc transgene cassette in mammalian 
tissues", Journal of International Scientific Publications: Agriculture \& Food, Vol. 2, pp. 448-456, 2014.

[81]. A. A. Shahid, S. Bano, S. Khalid, T. R. Samiullah, K. S. Bajwa \& M. A. Ali, "Biosafety assessment of transgenic Bt cotton on model animals", Advancements in Life Sciences, Vol. 3, Issue. 3, pp. 97-108, 2016.

[82]. M. A. Zia, S. A. Jan, Z. K. Shinwari, S. H. Shah \& A. T. Khalil, “ Impact of Bt Cotton on Animal Health", Global Veterinaria, Vol. 14, Issue. 3, pp. 377-381, 2015.

[83] H. Zeng, F. Tan, Y. Shu, Y. Zhang, Feng, Y. \& J. Wang, "The CrylAb protein has minor effects on the arbuscular mycorrhizal fungal communities after five seasons of continuous Bt maize cultivation", PloS one, Vol. 10, Issue. 12, e0146041, 2015.

[84] Y. B. Liu, H. Darmency, C. N. Stewart, W. Wei, Z. X. Tang \& K. P. Ma, "The effect of Bt-transgene introgression on plant growth and reproduction in wild Brassica juncea", Transgenic research, Vol. 24, Issue. 3, pp. 537-547, 2015.

[85] R. S. Keweshan, G. P. Head \& A. J. Gassmann, "Effects of pyramided Bt corn and blended refuges on western corn rootworm and northern corn rootworm (Coleoptera: Chrysomelidae)", Journal of economic entomology, Vol. 108, Issue. 2, pp. 720-729, 2015.

[86] D. Ferreira Holderbaum, M. Cuhra, F. Wickson, A. I. Orth, R. O. Nodari \& T. Bøhn, "Chronic responses of Daphnia magna under dietary exposure to leaves of a transgenic (event MON810) Btmaize hybrid and its conventional near-isoline", Journal of Toxicology and Environmental Health, Part A, Vol. 78, Issue. 15, pp. 993-1007, 2015.

[87] Y. Li, X. Zhang, X. Chen, J. Romeis, X. Yin \& Y. Peng, "Consumption of Bt rice pollen containing CrylC or Cry $2 A$ does not pose a risk to Propylea japonica (Thunberg)(Coleoptera: Coccinellidae)", Scientific reports, Vol. 5, pp. 7679, 2015.

[88] P. L. Dai, W. Zhou, J. Zhang, Z. H. Lang, T. Zhou, Q. Wang, et al,. "Effects of Bt crylAh corn pollen on immature worker survival and development of Apis cerana cerana", Journal of Apicultural Research, Vol. 54, Issue. 1, pp. 72-76, 2015.

[89] V. K. Sangode \& M. K. Rathod, "Effect of bt cotton on Spodoptera litura fabricius (Lepidoptera: Noctuidae)", International Journal of Pharmacology \& Biological Sciences, Vol. 9, Issue. 1, 2015.

[90] J. Deitloff, M. W. Dunbar, D. A. Ingber, B. E. Hibbard \& A. J. Gassmann, "Effects of refuges on the evolution of resistance to transgenic corn by the western corn rootworm, Diabrotica virgifera virgifera LeConte”, Pest management science, Vol. 72, Issue. 1, pp. 190-198, 2016.

[91] Y. Zhao, S. Zhang, J. Y. Luo, C. Y. Wang, L. M. Lv, X. P. Wang, C. L. Lei, et al,. "Bt proteins CrylAh and Cry2Ab do not affect cotton aphid Aphis gossypii and ladybeetle Propylea japonica”, Scientific reports, Vol. 6, pp. 20368, 2016.

[92] P. L. Dai, H. R. Jia, L. L. Geng \& Q. Y. Diao, “Bt toxin Crylle causes no negative effects on survival, pollen consumption, or olfactory learning in worker honey bees (Hymenoptera: Apidae)", Journal of economic entomology, Vol. 109, Issue. 3, pp. 1028-1033, 2016.

[93] L. Niu, W. Ma, C. Lei, J. L., Jurat-Fuentes \& L. Chen, "Herbicide and insect resistant Bt cotton pollen assessment finds no detrimental effects on adult honey bees", Environmental Pollution, Vol. 230, pp. 479-485, 2017.

[94] Z. X. Wang, Y. H. Li, K. L. He, S. X. Bai, T. T. Zhang, W. Z. Cai \& Z. Y. Wang, "Does Bt maize expressing CrylAc protein have adverse effects on the parasitoid Macrocentrus cingulum (Hymenoptera: Braconidae)?", Insect science, Vol. 24, Issue. 4, pp. 599-612, 2017.

[95] M. M. Khaing, X. Yang, M. Zhao, W. Zhang, B. Wang, J. Wei \& G. Liang, "Effects of antibiotics on biological activity of CrylAc in Bt-susceptible and Bt-resistant Helicoverpa armigera strains", Journal of invertebrate pathology, Vol. 151, pp. 197-200, 2018.

[96] L. Niu, A. Mannakkara, L. Qiu, X. Wang, H. Hua, C. Lei, W. Ma, et al,. "Transgenic Bt rice lines producing Cry1Ac, Cry2Aa or CrylCa have no detrimental effects on Brown Planthopper and Pond Wolf Spider", Scientific reports, Vol. 7, Issue. 1, pp. 1940, 2017.

[97] L. Niu, Z. Tian, H. Liu, H. Zhou, W. Ma, C. Lei \& L. Chen, "Transgenic Bt cotton expressing CrylAc/Cry $2 A b$ or CrylAc/EPSPS does not affect the plant bug Adelphocoris suturalis or the pollinating beetle Haptoncus luteolus", Environmental pollution, Vol. 234, pp. 788-793, 2018.

[98] Y. Yang, B. Zhang, X. Zhou, J. Romeis, Y. Peng \& Y. Li, "Toxicological and biochemical analyses demonstrate the absence of lethal or sublethal effects of cry1C-or cry2A-expressing Bt rice on the collembolan Folsomia candida", Frontiers in plant science, Vol. 9, p. 131, 2018.

[99] Q. Liu, W. Yang, M. Li, Y. Wu, Y. Wang, S. Wu, et al,. "Effects of 60-week feeding diet containing Bt rice expressing the CrylAb protein on the offspring of Inbred Wuzhishan pigs fed the same diet", Journal of agricultural and food chemistry, Vol. 65, Issue. 47, pp. 10300-10309, 2017.

[100] I. B. Salisu, A. A. Shahid, A. Yaqoob, A. Q. Rao, T. Husnain, "Effect of dietary supplementation of recombinant Cry and Cp4 epsps proteins on haematological indices of growing rabbits", Journal of animal physiology and animal nutrition, Vol. 103, Issue. 1, pp. 305-316, 2019. 